\title{
GROUPING OF THE EU CANDIDATE COUNTRIES AND EASTERN PARTNERSHIP COUNTRIES ACCORDING TO THE DEGREE OF SELF-SUFFICIENCY IN BASIC FOOD PRODUCTS
}

\author{
ANNA JANKOWSKA
}

\begin{abstract}
The article compares the European Union (EU) candidate countries $(C C)$ and the Eastern Partnership countries (EPC) in terms of their self-sufficiency in basic food products by analysing the average consumption of these products between 1992 and 2013. The countries were grouped according to their self-sufficiency ratios by Ward's method of cluster analysis. Studies have shown that in the first group of countries in 1992-1999 and 2000-2013 there were primarily Albania, Armenia, Bosnia and Herzegovina, Georgia and Macedonia, and they had the lowest self-sufficiency ratios for most products compared to the second and the third group of countries. In both periods, in the second group there were Azerbaijan and Turkey, which have the highest self-sufficiency ratio for fruit, and in the third group there were mainly Belarus, Moldova, Serbia and Ukraine. These countries were characterised by surplus in the production of most foods. Research showed that in the second period under consideration, Montenegro moved to a group of countries with a lower level of self-sufficiency. Studies proved that during the period under investigation the increase in the self-sufficiency of these countries resulted from greater production, lesser loss during production and lower consumption of the products under analysis.
\end{abstract}

Keywords: candidate countries, the Eastern Partnership countries, European Union, food self-sufficiency ratio, Ward's method.

JEL codes: E21, 057, Q10.

Dr Anna Jankowska, Uniwersytet Przyrodniczy w Poznaniu, Wydział Ekonomiczno-Społeczny, Katedra Ekonomii i Polityki Gospodarczej w Agrobiznesie; ul. Wojska Polskiego 28, 60-637 Poznań (anna.jankowska@up.poznan.pl).ORCID iD: 0000-0002-8966-9610. 


\section{Introduction}

Food self-sufficiency is a ratio showing that food-producing sectors of the economy are capable of satisfying the domestic demand (Sobiecki, 2007). The countries, where the agricultural sector is worse developed, often try to guarantee the maximum self-sufficiency in food products, although they are usually unprofitable in the natural area. Nevertheless, protection of the internal market and self-sufficiency are strictly related to a strategically important problem of food security (Beghin, Bureau and Park, 2003), which means that all citizens have access to any amount of food necessary for healthy and active life (Smutka, Spicka, Ishchukova and Selby, 2016). In many countries this ratio is a key priority in the production of basic foods, even if there is no comparative advantage of these products (Technical..., 1996; Grochowska, Łopaciuk, Rosiak and Szajner, 2013). It mostly applies to strategic products and under strictly specified conditions, because in the long run it is not legitimate to maintain domestic self-sufficiency, regardless of the comparative costs of production of these products (Woś, 1998). If the increase in production above this level is not justified by other causes, production may be expensive. In consequence, it will result in a loss of unexpected possibilities and profits, which agri-food trade might bring (Ritson, 1980). By taking part in the world food trade, it is possible to extend the assortment of domestic food products and gain income from exports so as to pay for imports (Gulbicka, 1998). On the one hand, proponents of food self-sufficiency defend the political right of states to insulate themselves from the vagaries of world food markets by increasing their reliance on domestic food production. On the other, critics argue that there are high costs to states that prioritize political over economic considerations in setting their food policies (Clapp, 2017). Food self-sufficiency is also viewed by many states as a politically important objective, not only as a strategy for building national pride, but also as a means to reduce vulnerability on the world political stage stemming from over-reliance on other countries for key supplies (O'Hagan, 1975). Some countries also promote food self-sufficiency as part of their broader economic development strategy, and in particular to strengthen their domestic farm sector (Clapp, 2017). The analysis of food self-sufficiency in a particular country enables prognosis of its adaptation to the Single European Market (SEM) after future extensions of the EU.

The aim of the article was to make a typology of the EU candidate countries and Eastern Partnership countries according to their self-sufficiency in main food products between 1992-1999 and 2000-2013. The article presents variation in self-sufficiency according to its determinants and compares it with the average consumption of these products in the countries under analysis.

\section{Material and methods}

The self-sufficiency of the CC and EPC in basic food products was analysed by means of the measure used in the EU and the Food and Agriculture Organisation of the United Nations (FAO). It shows the percentage of domestic production meeting the domestic demand for the basic products (consumed as food, used as animal feed, 
sowing material, material processed for consumption-unrelated purposes and waste). Food self-sufficiency shows the extent to which domestic production can meet the demand for consumption in a particular country. The algorithm of calculation of the food self-sufficiency ratio can be expressed by means of the following formula:

$$
\text { food self-sufficiency }=\frac{\text { domestic production }}{\text { consumption }} * 100 \%
$$

where consumption $=$ domestic production + volume of imports - volume of exports + variation in inventory (Smutka et al., 2016).

It has to be remembered, though, that the interpretation of the indicator is not so easy. For example, some countries that are more than self-sufficient in food at the country level can still have high levels of hunger and malnutrition among their population. Countries in this situation may produce more than enough of some food crops, but too little of others that are required for a healthy diet. Likewise, some countries that have this indicator well below $100 \%$ may have no problem in securing adequate food supplies for their population through a reliance on international trade (Clapp, 2017).

The analysed countries were grouped according to their self-sufficiency ratios by Ward's method of cluster analysis. The data was obtained from the FAOSTAT database, and the calculations were made, for instance, using the STATISTICA program.

\section{Results and discussion}

The average self-sufficiency ratios for the 1992-1999 and 2000-2013 periods were used in cluster analysis to group the CC and EPC (Fig. 1 and Fig. 2). The analysis started with a few input traits specifying the average self-sufficiency in basic products, i.e. cereals (excluding beer production), sugar crops, sugar beets, sugar and sweeteners, sugar, fruit (excluding wine production), vegetables, potatoes, milk (excluding butter production), bovine meat, pig meat, poultry meat, mutton and goat meat and eggs. However, due to excessive correlation of the traits the analysis was limited to self-sufficiency in the following products: cereals, fruit, sugar beets, bovine meat, pig meat, poultry meat in relation to which the highest value of the inverse of the diagonal matrices was 3.2.

The Ward cluster analysis made it possible to divide the analysed countries into three groups. The analysis showed that during such a long period of time there were only slight transformations within the tree main groups of countries. In 1992-1999, the first group consisted of Albania, Bosnia and Herzegovina, Macedonia, Armenia and Georgia. The second group consisted of Azerbaijan and Turkey and the third consisted of: Belarus, Montenegro, Serbia, Ukraine and Moldova. In principle, in 2000-2013, only Montenegro passed from the third to the first group of countries. The analysis showed that in both periods of time the third group was characterised by higher self-sufficiency ratios than the first and the second group in the following products: beef (about 130\%), cereals, excluding beer production (over 100\%) and pork - about $100 \%$. 

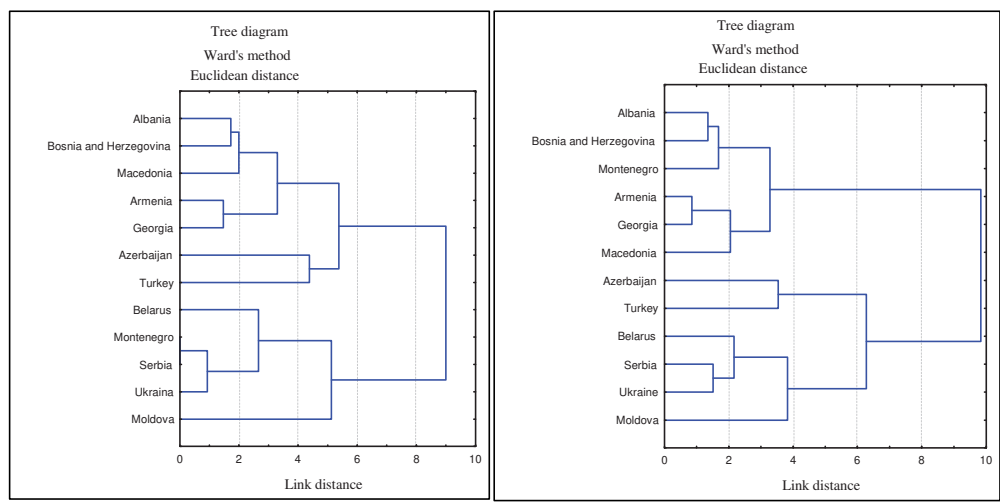

Self-sufficiency in (\%)

\begin{tabular}{|c|c|c|c|c|c|c|}
\hline & Bovine meat & Cereals & Fruit & Pig meat & Poultry meat & Sugar beets \\
\hline \multicolumn{7}{|c|}{ 1992-1999 } \\
\hline \multicolumn{7}{|c|}{$1^{\text {st }}$ group: Albania, Bosnia and Herzegovina, Macedonia, Armenia, Georgia } \\
\hline mean & 73.6 & 59.6 & 92.3 & 69.4 & 44.9 & 100.0 \\
\hline standard deviation & 11.7 & 17.2 & 10.9 & 21.0 & 8.9 & 49.8 \\
\hline $\mathrm{v}(\%)$ & 15.9 & 28.9 & 11.8 & 30.3 & 19.9 & $81.7(50.0)$ \\
\hline \multicolumn{7}{|c|}{$2^{\text {nd }}$ group: Azerbaijan, Turkey } \\
\hline mean & 89.1 & 82.4 & 106.8 & 28.9 & 77.5 & 220.5 \\
\hline standard deviation & 6.0 & 20.2 & 11.9 & 29.0 & 24.0 & 120.5 \\
\hline $\mathrm{v}(\%)$ & 6.7 & 24.5 & 11.1 & $100.0(100.0)$ & 30.9 & $54.6(54.6)$ \\
\hline \multicolumn{7}{|c|}{$3^{\text {rd }}$ group: Belarus, Montenegro, Serbia, Ukraine, Moldova } \\
\hline mean & 130.9 & 100.2 & 100.8 & 102.6 & 96.1 & 104.5 \\
\hline standard deviation & 48.6 & 11.3 & 16.5 & 4.6 & 5.0 & 9.0 \\
\hline $\mathrm{v}(\%)$ & 37.1 & 11.3 & 16.4 & 4.5 & 5.2 & 8.6 \\
\hline \multicolumn{7}{|c|}{$2000-2013$} \\
\hline \multicolumn{7}{|c|}{1 st group: Albania, Bosnia and Herzegovina, Montenegro, Armenia, Georgia, Macedonia } \\
\hline mean & 70.9 & 47.7 & 86.5 & 48.6 & 33.9 & 49.0 \\
\hline standard deviation & 18.7 & 20.9 & 18.0 & 8.6 & 20.4 & 49.7 \\
\hline $\mathrm{v}(\%)$ & 26.3 & 43.8 & 20.8 & 17.7 & $53.9(66.2)$ & $100.0(100.2)$ \\
\hline \multicolumn{7}{|c|}{$2^{\text {nd }}$ group: Azerbaijan, Turkey } \\
\hline mean & 97.1 & 83.0 & 124.1 & 12.5 & 95.0 & 379.1 \\
\hline standard deviation & 1.5 & 18.6 & 4.5 & 12.5 & 13.7 & 279.2 \\
\hline $\mathrm{v}(\%)$ & 1.5 & 22.4 & 3.6 & $100.0(100.0)$ & 14.4 & $73.6(73.6)$ \\
\hline \multicolumn{7}{|c|}{$3^{\text {rd }}$ group: Belarus, Serbia, Ukraine, Moldova } \\
\hline mean & 134.7 & 118.9 & 97.4 & 97.1 & 86.1 & 101.8 \\
\hline standard deviation & 33.5 & 20.5 & 28.6 & 9.3 & 14.9 & 1.4 \\
\hline $\mathrm{v}(\%)$ & 24.9 & 17.2 & 29.4 & 9.6 & 17.3 & 1.4 \\
\hline
\end{tabular}

In all analyses where the coefficient of variation exceeded $50 \%$ a median was calculated instead of a mean, while the coefficients of variation calculated for position measures are given in brackets.

Fig. 1 and Fig. 2. Ward's method of cluster analysis of the CC and EPC according to their self-sufficiency in the basic food products between 1992 and 1999 and between 2000 and 2013.

Source: the author's compilation based on FAOSTAT (data accesss: 29 September 2017). 
The self-sufficiency ratios in fruit were the highest for Azerbaijan and Turkey above $100 \%$ (they were greater than the average ratios in the EU). However, it is noteworthy that the EU Member States were not self-sufficient in fruit, so the CC and EPC may be significant competitors. This group of countries also has higher almost all self-sufficiency ratios than the first group of countries except for the pig meat because of cultural reasons. The first group of countries was, in turn, characterised by rather low self-sufficiency ratios in most of the analysed products except for fruit and sugar beets (in the first analysed period).

Comparing the two surveyed periods in all groups of countries, self-sufficiency decreased in the case of most products with the exception of Azerbaijan and Turkey where the self-sufficiency ratios were higher for most products. For all products, self-sufficiency decreased in Montenegro, in cereals, pork and sugar beet (even by 50 to 100 percentage points), which led to the transfer of this country to the first group of countries with lower self-sufficiency ratios.

The future integration of the CC and EPC with the EU forces some changes in the structure of agricultural production. Crop production is one of the main branches of agricultural production because it provides products to other branches of agriculture and to the industry (Grontkowska, 2002). For example, the production of cereals in Ukraine is as much as $35 \%$ larger than the domestic consumption (Table 1). During the period under study the self-sufficiency ratio increased in Ukraine. It is most likely that it was caused by the increasing production and decreasing consumption (by about 13\%) although the use of cereals for processing increased significantly - by nearly $72 \%{ }^{1}$. The self-sufficiency in cereals production differed considerably in the other countries. It ranged from about $40 \%$ of the domestic demand in Georgia and Armenia to about 113\% in Moldova and Serbia. During the period under study the ratio decreased in Georgia, because the processing of cereals increased by nearly 2.5 times, the consumption grew by nearly $40 \%$, but the production dropped slightly. Apart from that, the annual consumption of cereals was high in Georgia, i.e. $196 \mathrm{~kg}$ per capita (Table 2). The self-sufficiency ratio in cereals was also low in Armenia, although it tended to increase during the period under study. The production increased, whereas the consumption dropped by about $16 \%$. However, the use of cereals for animal feeds increased significantly, i.e. by nearly 2.5 times. It is noteworthy that the annual consumption of cereals was also high in Turkey, Azerbaijan and Bosnia and Herzegovina, i.e. about $212 \mathrm{~kg}$ per capita. It was two times greater than the average consumption in the EU. It is noteworthy that the consumption style in the CC and EPC is similar to the style in the Mediterranean EU Member States, such as Greece, Italy and Malta, where the consumption of cereals, fruit and vegetables is high, whereas potato consumption is low. The consumption of lowly processed products made at a low cost is usually higher than in the EU. By contrast, the consumption of products made at a higher cost, e.g. meat and sugar, is lower than the average consumption per capita in the EU.

\footnotetext{
${ }^{1}$ The data concerning the production, processing, sowing and animal feeding were acquired from FAOSTAT; accessed on 29 September 2017.
} 
There was very high diversification in self-sufficiency in sugar beets. This is evidenced by the calculated standard deviation, which in both analysed periods was the highest for the first and the second group of countries among all the analysed products. The highest overproduction was noted in Azerbaijan, where it amounted to $550 \%$, on average. Although during the period under study the production of sugar beets fluctuated considerably, it increased by more than 12 times. In the other countries (except Bosnia and Herzegovina, Montenegro and Georgia, where these crops have not been cultivated since about 1996) the self-sufficiency in sugar beets amounted to nearly $100 \%$.

As far as fruit is concerned, the average self-sufficiency ratio in all the countries was slightly lower than the vegetable self-sufficiency ratio and it amounted to 97\%. There was overproduction of fruit in six countries. The highest surplus (about $30 \%$ ) was noted in Moldova and Turkey. Moldova was characterised by a high fruit self-sufficiency ratio although the fruit production dropped, whereas its use as animal feed increased by about $20 \%$. However, the amount of fruit for processing decreased by as much as $62 \%$ and the consumption dropped slightly, too. It is most likely that the fruit surplus in Turkey was caused by a nearly $63 \%$ increase in production. It was much higher than the increase in processing, which amounted to nearly $44 \%$, and the increase in consumption, i.e. $8 \%$. Apart from that, Turkey was characterised by the highest annual fruit consumption, i.e. $118 \mathrm{~kg}$ per capita, on average. Fruit consumption was also high in Montenegro. As far as the other countries are concerned, the annual fruit consumption ranged from $49.4 \mathrm{~kg}$ per capita in Georgia to $94 \mathrm{~kg}$ per capita in Macedonia. For this product, the highest volatility coefficient of $29.4 \%$ which shows the average variation, occurred in the $3^{\text {rd }}$ analysed group of countries in the second analysed period.

Good results in crop production guarantee the abundance of cheap feeds for animal production. The analysis of meat self-sufficiency shows that the ratios differed by the type of meat. The highest average self-sufficiency ratio in all the countries was noted for mutton and goat meat (about 109\%). The ratio for bovine meat amounted to $98 \%$, whereas the ratios for pig meat and poultry meat were similar, i.e. about $69 \%$. 


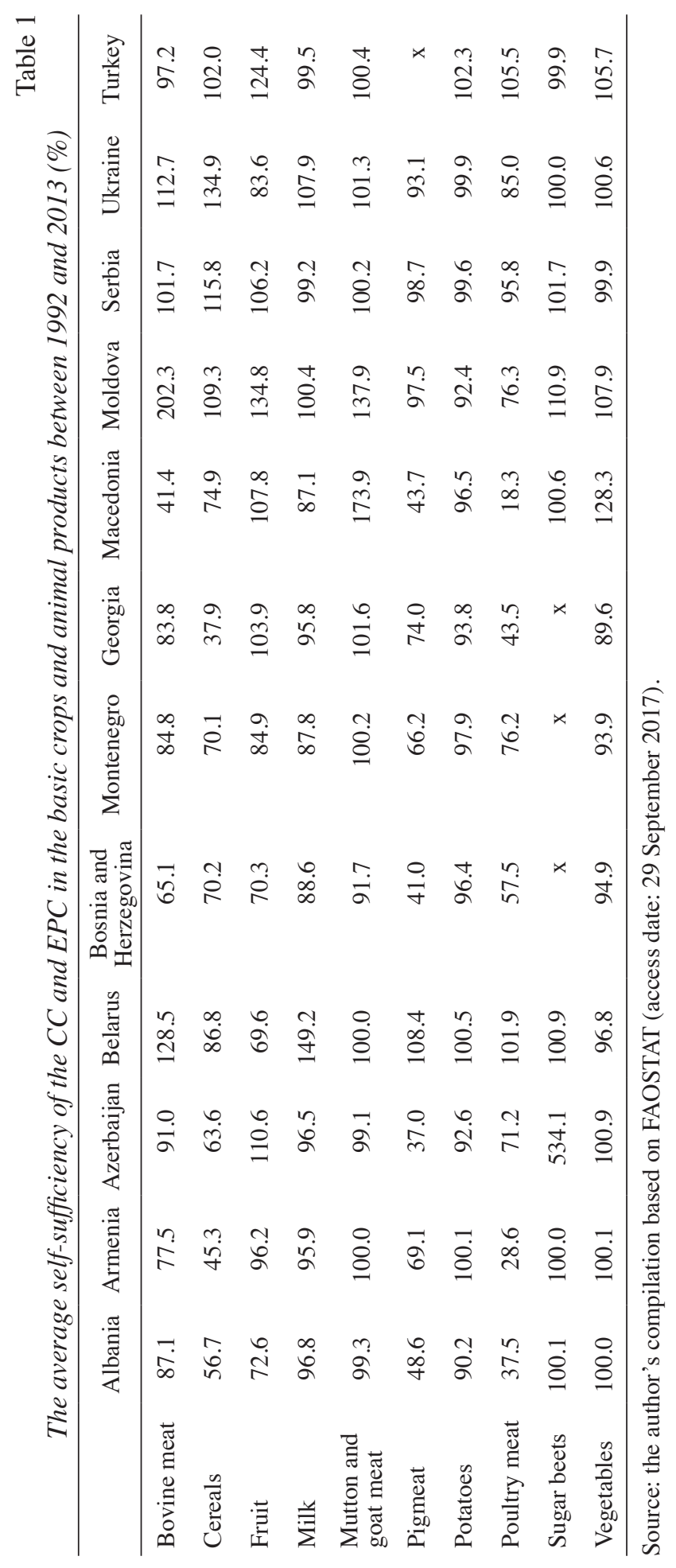




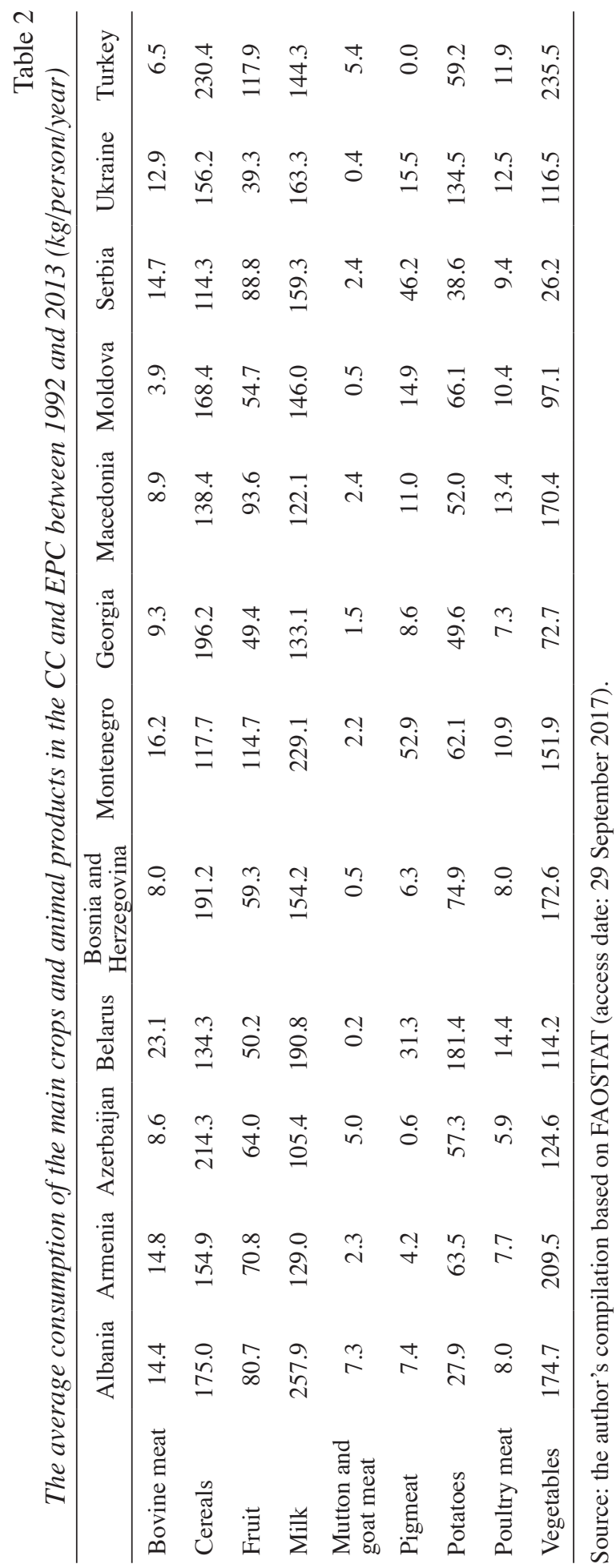


It is noteworthy that some of the countries under study are significant beef producers (Belarus, Moldova, Serbia, Ukraine and Turkey). Beef production may be an alternative to the farms which will have to abandon dairy cattle breeding due to restrictive sanitary requirements (Kossakowska and Lewandowski, 2007). The highest bovine meat self-sufficiency was noted in Moldova, where it exceeded the domestic demand by more than $100 \%$ (the self-sufficiency ratio was $202.3 \%$ ). There was such a high surplus in that country although beef production dropped by more than $89 \%$. Apart from that, it is noteworthy that during the period under analysis bovine meat consumption decreased by nearly $90 \%$. The annual consumption was the lowest among the CC and EPC - only $3.9 \mathrm{~kg}$ per capita. There was overproduction of beef in Belarus and Ukraine (by about 20\%) and minimal overproduction in Serbia. It is noteworthy that the annual bovine meat consumption was the highest in Belarus and it was even slightly higher than the annual beef consumption in the EU, i.e. $23.1 \mathrm{~kg}$ per capita. There was deficit of the product in other countries - the highest in Macedonia (the self-sufficiency ratio was about 40\%) and the lowest in Turkey $(2.8 \%)$ and Azerbaijan (9\%). It is worth adding that for this product the highest standard deviation occurred for $3^{\text {rd }}$ group in both analysed periods.

As far as pig meat is concerned, there was a slight surplus only in Belarus, where the self-sufficiency ratio amounted to $108.4 \%$. There were slight deficits (about 1.3-6.9\%) in Moldova, Serbia and Ukraine. There were bigger deficits in the other countries, ranging from about $60 \%$ in Azerbaijan, and Bosnia and Herzegovina, Macedonia and Albania to 30\% in Georgia and Armenia. The average annual pork consumption was the lowest in Azerbaijan, i.e. only $0.6 \mathrm{~kg}$ per capita (due to the influence of Islam). The average annual pork consumption was the highest in Montenegro and Serbia, where it amounted to $49.5 \mathrm{~kg}$ per capita and it was slightly greater than the average pork consumption in the EU. It is worth mentioning that for this product the highest coefficient of variation occurred in the $2^{\text {nd }}$ group in both analysed periods and amounted to $100 \%$, which indicates a very large differentiation.

In poultry meat production, there were slight surpluses in Belarus and Turkey. There were very low self-sufficiency ratios in Macedonia (less than 20\%), Armenia and Albania (about 30\%). The average annual consumption of poultry was the highest in Belarus, Macedonia, Ukraine and Turkey, i.e. $13.1 \mathrm{~kg}$ per capita, but it was lower than the average consumption in the EU.

It is worth mentioning that the analysed countries are very differentiated in terms of the level of development of the agricultural sector and factors affecting it (Jankowska, 2016). However, the analysis of the self-sufficiency of the CC and EPC in the main groups of crops and animal products showed that Belarus, Moldova, Serbia, Ukraine and Turkey were almost self-sufficient in the main groups of food products. It is noteworthy that self-subsistence and semi-subsistence farming guarantees some food security and socioeconomic stability in rural areas in most of the countries under the study (Synthesis..., 2006).

To sum up, the main agricultural sectors in Ukraine and Belarus are cereals, oilseeds, potatoes, sugar beets, meat and dairy production. Azerbaijan, Armenia, Georgia and Moldova have favourable conditions for vegetables, fruit and cereals, 
with wine being the most important high-value agricultural product. In the region's meat sector, poultry meat is more important than pig meat, which is more important than beef and veal production, in volume terms.

Some of the countries surveyed, strongly depend on food imports. This is especially the case for wheat markets in Armenia, Azerbaijan and Georgia. In addition, integration with international markets is particularly strong for export-oriented $\mathrm{CC}$ and EPC markets, such as the wheat market in Ukraine. Moreover, the results indicate strong integration in these CC and EPC markets, which largely depend on the import of food from outside of the region, such as pork, beef and the powdered milk market.

Relatively large untapped agricultural potentials exist in CC, but especially in the EPC. These disruptions were likely caused by military conflicts and the dissolution of economic ties between the former Yugoslav republics. Armenia and Georgia exhibit a similar image. Both countries experienced conflict, land reform and the cutting of economic links in the early 1990s (Regional..., 2017). During the 1990s, after the collapse of the Soviet Union, the agricultural sector was suddenly faced with increasing international competition, while at the same time, subsides were drastically reduced and productivity declined. These developments lead to high abandonment rates of agricultural land and comparatively low yields. Causes of untapped potentials are many, with (a combination of) biophysical, economic and institutional factors hampering development. Abandoned land may be remote and face poor agro-environmental conditions, while low yields are due to limitations in management skills, water and fertilisers application. To untap the potentials it is required to make investments in (yield enhancing) input use, machinery, sheds, storage and in access to education, knowledge, finance, functioning land markets, property right protection and other institutions that a market-driven agricultural system needs. Government policies are not always conducive to improved efficiency and competitiveness of the sector, and all analysed countries score relatively poor on "good governance", a crucial factor for a country's business development. Moreover, in most sectors - except for poultry - farmers are poorly integrated in the supply chain, due to an underdeveloped processing sector in almost all supply chains in all countries. The latter explains why the sector generates relatively little value added and exports mainly raw commodities (such as grains and oilseeds).

To raise the unused agricultural potentials of CC and EPC, higher investments in the physical infrastructure, particularly in storing and transportation capacities, are required. Improvements in the institutional environment (land market regulations, property rights, insurance system) could increase private investments. Furthermore, improved education systems, more agricultural research and development activities, and better access to financial resources would be supportive.

Literature research analysis shows that the agricultural policy of the $\mathrm{CC}$ and EPC has become quite differentiated, which is manifested in varying numbers of pre-transitional policy patterns still in existence, different levels of market-price support, trade policy liberalisation engagement and in the amount of funds available for agricultural policy. Yet, the priorities of agricultural policy exposed in strategic documents are quite similar, with a strong production-oriented character that 
emphasises food security. There are also other priorities, which indicate the primarily developmental role of agricultural policy, such as increasing competitiveness, productivity and export orientation. Policy priorities may be similar and only vary between countries in their emphasis, yet the choice and volume of individual instruments differ (Van Berkum et al., 2016).

\section{Conclusions}

Although the climate in the CC and EPC is similar to the climate in the south and east EU Member States, the productivity is usually lower, due to greater fragmentation of agriculture. Despite this the typology of the CC and EPC showed that some countries (Belarus, Moldova, Serbia, Ukraine and Turkey) achieved, in general, higher self-sufficiency ratios for most products under study (especially for bovine meat, cereals and pig meat). In turn, the self-sufficiency ratios in fruit were the highest in Azerbaijan and Turkey and the ratios were greater than the average ratios in the EU. However, it is noteworthy that the EU Member States were not self-sufficient in these products, so the CC and EPC may be significant competitors. Moreover, the self-sufficiency ratios for most analysed products were the lowest in Albania, Armenia, Azerbaijan, Bosnia and Herzegovina and Georgia and the ratios were also lower than the average ratios in the EU. What is more, it should be mentioned that the average self-sufficiency for the production of fruit and sugar beets increased in the CC and EPC during the two analysed periods.

Variability in the self-sufficiency ratio depends on numerous factors, such as the climate, area of farmland, yield volume, changes in production and consumption trends as well as reforms of agriculture, etc. The research showed that during the period under study the variation in self-sufficiency in the CC and the EPC was influenced by the increase in production, lesser loss during production as well as lower consumption of the products under analysis.

Although the changes in the self-sufficiency and in the volume of agricultural production were slow and only some tendencies were manifested, they indicate the extent to which the agriculture in these countries was adjusted to the new guidelines set by the Common Agricultural Policy (CAP). Apart from that, the production structure in the CC and EPC clearly indicated specialisation, which is usually determined by the climate and natural conditions existing in these countries. 


\section{References}

Beghin, J.C., Bureau, J.C., Park, S.J. (2003). Food security and agricultural protection in South Korea. American Journal of Agricultural Economics, No. 85, pp. 618-632.

Clapp, J. (2017). Food self-sufficiency: Making sense of it, and when it makes sense. Food Policy, No. 66, pp. 88-96.

Grochowska, R., Łopaciuk, W., Rosiak, E., Szajner, P. (2013). Światowa produkcja biopaliw w kontekście bezpieczeństwa żywnościowego. Program Wieloletni 2011-2014, No. 70. Warszawa: IERiGŻ-PIB.

Grontkowska, A. (2002). Organizacja produkcji roślinnej. In: B. Klepacki (ed.), Procesy dostosowawcze produkcji roślinnej $w$ Polsce $w$ kontekście integracji $z$ Unią Europejska. Warszawa: Wieś Jutra, pp. 29-43.

Gulbicka, B. (1998). Wyżywienie. In: A. Woś (ed.), Encyklopedia agrobiznesu. Warszawa: Wydawnictwo Fundacja Innowacja, pp. 940-949.

Jankowska, A. (2016). Typologia rolnictwa krajów kandydujących do Unii Europejskiej ze względu na wybrane cechy sektora rolnego. Zeszyty Naukowe SGGW, Problemy Rolnictwa Światowego, No. 16(31), vol. 2, pp. 145-153.

Kossakowska, J., Lewandowski, R. (2007). Szanse rozwoju krajowego rynku wołowiny. Biuletyn Informacyjny ARR, No. 1(187), pp. 4-9.

O'Hagan, J.P. (1975). National self-sufficiency in food. Food Policy, No. 1(5), pp. 355-366.

Regional Overview of Food Insecurity Europe and Central Asia. The Food Insecurity Transition 2016 (2017). Budapest: FAO.

Ritson, C. (1980). Self-sufficiency and food security, CAS Paper. University of Reading.

Smutka, L., Spicka, J., Ishchukova, N., Selby, R. (2016). Agrarian import ban and its impact on the Russian and European Union agrarian trade performance. Agricultural Economics, no. 62(11), pp. 493-506.

Sobiecki, R. (2007). Globalizacja a funkcje polskiego rolnictwa. Warszawa: Wydawnictwo SGH.

Synthesis report (2006). ARCOTRASS - Consortium Study on the State of Agriculture in Five Applicant Countries.

Technical Background Document (1996). Food and International Trade. Retrieved from: www. fao.org/docrep/003/w2612e/w2612e12.htm (access date: 27.10.2016).

Van Berkum, S. (2009). An assessment of the competitiveness of the dairy supply chain in new member states, candidate and potential candidate countries. Agripolicy Enlargement Network for Agripolicy Analysis. European Commission.

Van Berkum, S., Banse, M., Deppermann, A., Erjavec, E., Djuric, I., Philippides, G., Wolf, V. (2016). Synthesis report: Findings of the AGRICISTRADE project. Brussels: European Commission.

Woś, A. (1998). Autarkia gospodarcza w rolnictwie. In: A. Woś (ed.), Encyklopedia agrobiznesu. Warszawa: Wydawnictwo Fundacja Innowacja. 


\title{
GRUPOWANIE KRAJÓW KANDYDUJĄCYCH DO UE I KRAJÓW PARTNERSTWA WSCHODNIEGO ZE WZGLĘDU NA POZIOM SAMOWYSTARCZALNOŚCI ŻYWNOŚCIOWEJ W KONTEKŚCIE PODSTAWOWYCH PRODUKTÓW SPOŻYWCZYCH
}

\begin{abstract}
Abstrakt
W artykule porównano kraje kandydujące do UE (CC) i kraje Partnerstwa Wschodniego $(K P W)$ pod względem poziomu ich samowystarczalności $w$ zakresie podstawowych produktów spożywczych poprzez analize średniego spożycia tych produktów w latach od 1992 do 2013. Kraje pogrupowano wedtug wskaznika ich samowystarczalności przy użyciu metody analizy skupień Warda. Badania pokazały, że w pierwszej grupie krajów w latach 1992-1999 i 2000-2013 znalazły się przede wszystkim Albania, Armenia, Bośnia i Hercegowina, Gruzja i Macedonia, które miały najniższe wskaźniki samowystarczalność dla większości produktów w porównaniu z druga i trzecia grupa krajów. W obydwu okresach $w$ drugiej grupie znalazły się Azerbejdżan i Turcja, które miały najwyższe wskaźniki samowystarczalność w sektorze owoców, a w trzeciej grupie - Białoruś, Mołdawia, Serbia i Ukraina. Kraje te charakteryzowały sie nadwyżka w produkcji większości sektorów. Badania wykazały, że w drugim okresie Czarnogóra przesunęła się do grupy krajów o niższym poziomie samowystarczalności. Analiza dowiodła, że w okresie objętym badaniem wzrost samowystarczalności tych krajów wynikat z wyższej produkcji, niższych strat podczas produkcji i niższego poziomu spożycia analizowanych produktów.
\end{abstract}

Słowa kluczowe: kraje kandydujące, kraje Partnerstwa Wschodniego, Unia Europejska, wskaźnik samowystarczalności żywieniowej, metoda Warda.

Accepted for print: 18.12.2018.

Unless stated otherwise all the materials on the website are available under the Creative Commons Attribution 4.0 International license.

Some rights reserved to the Institute of Agricultural and Food Economics - National Research Institute.

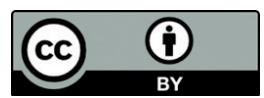

